\title{
Identification of Some Oomycetes by Reverse Dot Blot Hybridization
}

\author{
C. André Lévesque, Colleen E. Harlton, and Arthur W. A. M. de Cock
}

First and second authors: Pacific Agri-Food Research Centre, Agriculture and Agri-Food Canada, Summerland, British Columbia V0H 1Z0; third author: Centraalbureau voor Schimmelcultures, Yeast Division, Julianalaan 67, 2628 BC Delft, Netherlands. Accepted for publication 21 November 1997.

\begin{abstract}
Lévesque, C. A., Harlton, C. E., and de Cock, A. W. A. M. 1998. Identification of some oomycetes by reverse dot blot hybridization. Phytopathology 88:213-222.

An assay was developed that can identify unknown isolates of Pythium or Phytophthora species in a single hybridization. This reverse dot blot system is based on arrays of species-specific amplified fragments or oligonucleotides derived from the internal transcribed spacer (ITS) region, which are blotted as dots on a nylon membrane. By using total DNA from a sample as the template, universal primers, and digoxigenindUTP, the ITS was amplified and labeled simultaneously by the polymerase chain reaction (PCR). A small aliquot of the resultant labeled and amplified product was used as a probe for hybridization to a dot blot membrane that contained the immobilized species-specific oligonucleo-
\end{abstract}

ABSTRACT tides or amplified PCR fragments. The reverse dot blot system based on arrays of oligonucleotides showed far fewer cross-hybridizations than one based on entire amplified ITS I fragments. Unknown species can be identified simply by visualizing the positive hybridization reaction between the DNA labeled directly from the sample and the immobilized specific oligonucleotide. Currently, the assay can be used to identify Pythium aphanidermatum, P. ultimum, P. acanthicum, and Phytophthora cinnamomi. An oligonucleotide that was originally designed to identify Phytophthora hybridized to 10 of the 14 Phytophthora species tested. Another oligonucleotide designed to identify oomycetes hybridized to the 68 species tested, which represented two of the four orders of this phylum.

Additional keywords: chemiluminescence, detection, diagnosis, NIH IMAGE.
Identification of oomycetes is still based primarily on morphological characters $(6,40)$. High variability within key structures leads to considerable overlap between species and to potential errors in identification, especially for mycologists who do not have many years of experience working with this group $(13,14)$. Molecular techniques can be useful not only to identify species, but to better understand the evolutionary relationships between species $(7,25)$. Separation of proteins by electrophoresis has been used to differentiate Pythium species (4,9), and a species-specific antibody for $P$. ultimum has been developed (44). Restriction fragment length polymorphism (RFLP) of total DNA (29) or of amplified ribosomal DNA $(8,10)$ has been used to differentiate and study relationships between certain Pythium species. Spacers of the genomic ribosomal DNA cistron amplified by polymerase chain reaction (PCR) have been used as species-specific probes in standard dot blot assays $(23,30)$. For some species of Phytophthora, oligonucleotide probes were designed by comparing their internal transcribed spacer (ITS) sequences $(26,27)$, and speciesspecific genomic DNA probes selected from random clones have been developed for $P$. citrophthora and $P$. nicotianae (synanamorph $P$. parasitica) $(16,17)$.

These techniques, particularly the standard dot blot and antibody-based assays, are convenient to test many samples for the presence of one particular pathogen. However, they are not efficient to identify an isolate when there are many possibilities to be addressed (e.g., when isolates lack reproductive structures) or when several different pathogens that might be present within a given sample are to be tested simultaneously. There are some recent studies in which a few pathogens were assayed simultaneously. For example, two species-specific pairs of primers were simultaneously used in a single PCR reaction to test for the

Corresponding author: C. A. Lévesque; E-mail address: LevesqueCA@em.agr.ca

Publication no. P-1998-0106-01R

(C) 1998 Department of Agriculture and Agri-Food, Government of Canada presence of two pathogens $(3,18)$. An interesting variation of this technique was developed by using a fluorescent dye-labeled nested primer located between a pair of specific primers (38). This technology, called TaqMan, can potentially detect up to three pathogens in a single reaction without having to visualize the results on an agarose gel. Such multiplex PCR reactions are limited by the number of primer pairs that can be used in a single reaction, the number of bands that can be clearly identified to a species level without giving false positives, and/or the number of different fluorescent dyes currently available. There is therefore a need for an approach in the molecular identification of fungi that could detect large numbers of species at once.

A relatively novel technique called the reverse dot blot has been successfully used to detect, in a single assay, a range of mutations related to different human disorders (36) and more recently to monitor bacteria from environmental samples (41). This technique involves the use of multiplex PCR to simultaneously amplify and label the regions of the DNA that are used to design the specific oligonucleotides. The labeled PCR products are used as probes for hybridization with a membrane that contains an array of specific oligonucleotides. Mutations or species present in a sample are determined from the positive reactions in the hybridization test. Reverse dot blot has also been used with specific PCR fragments blotted on the membrane and labeled genomic DNA used for probing (24). In a similar fashion, it was used with a single dot to detect Erwinia amylovora (33).

The objective of this study was to demonstrate the feasibility of the reverse dot blot technique for the identification of selected oomycetes: Pythium aphanidermatum, P. acanthicum, P. ultimum, and Phytophthora cinnamomi. Identification at the phylum level for the oomycetes and at the genus level for Phytophthora was also undertaken.

\section{MATERIALS AND METHODS}

Fungal collection. A collection of 166 isolates was used in this study (Table 1). Cultures of oomycetes were maintained on slants 
TABLE 1. Isolates used for various parts of this study

\begin{tabular}{|c|c|c|c|c|c|c|c|c|}
\hline Phylum & Order & Species & Culture $^{\mathrm{a}}$ & Origin & Host or substrate & Fig. $1^{\mathrm{b}}$ & $\begin{array}{l}\text { Figs. } \\
3-6^{c}\end{array}$ & $\begin{array}{l}\text { RDBH } \\
\text { tested }^{d}\end{array}$ \\
\hline \multirow[t]{3}{*}{ Ascomycota } & Diaporthales & Diaporthe vaccinii & FLC 93014B & MA & Vaccinium macrocarpon & & $\mathrm{x}$ & $\mathrm{x}$ \\
\hline & Eurotiales & Penicillium lividum & NRRL754 & $\mathrm{NA}^{\mathrm{e}}$ & NA & & $\mathrm{x}$ & $\mathrm{x}$ \\
\hline & Unknown & Allantopomopsis lycopodina & FLC 85195 & MA, U.S.A. & Vaccinium macrocarpon & & & $\mathrm{x}$ \\
\hline \multirow[t]{3}{*}{ Chytridiomycota } & Blastocladiellales & Allomyces macrogynus & ATCC 38327 & NA & Pond soil & & $\mathrm{x}$ & $\mathrm{x}$ \\
\hline & & Blastocladiella emersonii & ATCC 22665 & PA, U.S.A. & Pond water & & $\mathrm{x}$ & $\mathrm{x}$ \\
\hline & Spizellomycetales & Olpidium bornovanus & DMR & NA & Cucumis sativus & & $\mathrm{x}$ & $\mathrm{x}$ \\
\hline \multirow{69}{*}{ Oomycota } & Saprolegniales & Saprolegnia ferax & ATCC 36051 & Canada & Lake water & & $\mathrm{x}$ & $\mathrm{x}$ \\
\hline & & Aphanomyces euteiches & ATCC 46690 & WI, U.S.A. & Pisum sativum & & $\mathrm{x}$ & $\mathrm{x}$ \\
\hline & & Dictyuchus monosporus & ATCC 34931 & TN, U.S.A. & Lake water & & $\mathrm{x}$ & $\mathrm{x}$ \\
\hline & & Achlya recurva & ATCC 16088 & MD, U.S.A. & Soil & & $\mathrm{x}$ & $\mathrm{x}$ \\
\hline & & Achlya sp. & CAL K2 & B.C., Canada & Hydroponic solution & & $\mathrm{x}$ & $\mathrm{x}$ \\
\hline & Peronosporales & Peronophythora litchii & ATCC 28739 & Taiwan & Litchi chinensis & & $\mathrm{x}$ & $\mathrm{x}$ \\
\hline & & Pythium acanthicum & CBS 377.34 & Sweden & Solanum tuberosum & $\mathrm{x}$ & $\mathrm{x}$ & $\mathrm{x}$ \\
\hline & & P. acanthicum & DJSB 500 & Ont., Canada & Soil & & & $\mathrm{x}$ \\
\hline & & P. acanthicum & ZGA & $\mathrm{NC}$ & Turfgrass & & & $\mathrm{x}$ \\
\hline & & P. acanthicum & DJSB 178 & Ont., Canada & Hordeum vulgare & & & $\mathrm{x}$ \\
\hline & & P. acanthicum & FNM 66-1 & FL, U.S.A. & Soil & & & $\mathrm{x}$ \\
\hline & & P. acanthicum & FNM A-6 & NC, U.S.A. & Soil & & & $\mathrm{x}$ \\
\hline & & P. acanthophoron & DJSB 496 & B.C., Canada & Malus pumila & & $\mathrm{x}$ & $\mathrm{x}$ \\
\hline & & P. afertile & DJSB 417 & Alb., Canada & Triticum aestivum & & $\mathrm{x}$ & $\mathrm{x}$ \\
\hline & & P. aphanidermatum & DJSB 444 & B.C., Canada & Cucumis sativus & & & $\mathrm{x}$ \\
\hline & & P. aphanidermatum & CBS 118.80 & France & NA & $\mathrm{x}$ & & $\mathrm{x}$ \\
\hline & & P. aphanidermatum & DJSB 206 & Ont., Canada & Pinus resinosa & & & $\mathrm{x}$ \\
\hline & & P. aphanidermatum & ZGA & NC, U.S.A. & Turfgrass & & & $\mathrm{x}$ \\
\hline & & P. aphanidermatum & DJSB 206 & Ont., Canada & Pinus resinosa & & & $\mathrm{x}$ \\
\hline & & P. aphanidermatum & DJSB 740 & B.C., Canada & Cucumis sativus & & & $\mathrm{x}$ \\
\hline & & P. aphanidermatum & JM 100 & B.C., Canada & Cucumis sativus & & $\mathrm{x}$ & $\mathrm{x}$ \\
\hline & & P. aphanidermatum & FNM 96-4 & FL, U.S.A. & Soil & & & $\mathrm{x}$ \\
\hline & & P. aphanidermatum & FNM 1992-31 & South Africa & NA & & & $\mathrm{x}$ \\
\hline & & P. aphanidermatum & FNM 1991-3 & Japan & NA & & & $\mathrm{x}$ \\
\hline & & P. aphanidermatum & FNM 1987-61 & Mexico & Lactuca sativa & & & $\mathrm{x}$ \\
\hline & & P. aphanidermatum & WC $25-2$ & NA & NA & & & $\mathrm{x}$ \\
\hline & & P. aphanidermatun & WC 21-4 & NA & NA & & & $\mathrm{x}$ \\
\hline & & P. aquatile & CAL 1695 & B.C., Canada & Hydroponic solution & & $\mathrm{x}$ & $\mathrm{x}$ \\
\hline & & P. aristosporum & ZGA & NC, U.S.A. & Turfgrass & & & $\mathrm{x}$ \\
\hline & & P. aristosporum & CBS 263.38 & Sask., Canada & Triticum aestivum & & $\mathrm{x}$ & $\mathrm{x}$ \\
\hline & & P. arrhenomanes & DJSB 671 & Man., Canada & Avena fatua & $\mathrm{x}$ & & $\mathrm{x}$ \\
\hline & & P. arrhenomanes & CBS 324.62 & WI, U.S.A. & Zea mays & & $\mathrm{x}$ & $\mathrm{x}$ \\
\hline & & P. carolinianum & ZGA & NC, U.S.A. & Turfgrass & & $\mathrm{x}$ & $\mathrm{x}$ \\
\hline & & P. catenulatum & CBS 842.68 & SC, U.S.A. & Turfgrass & & $\mathrm{x}$ & $\mathrm{x}$ \\
\hline & & P. coloratum & DJSB 401 & NA & NA & $\mathrm{x}$ & & $\mathrm{x}$ \\
\hline & & P. coloratum & CBS 154.64 & S. Australia & Soil & & $\mathrm{x}$ & $\mathrm{x}$ \\
\hline & & P. deliense & CBS 114.84 & Peru & Solanum tuberosum & & & $\mathrm{x}$ \\
\hline & & P. deliense & CBS 314.33 & Indonesia & Nicotiana tabacum & & $\mathrm{x}$ & $\mathrm{x}$ \\
\hline & & P. dissotocum & CBS 166.68 & OH, U.S.A. & Triticum aestivum & $\mathrm{x}$ & $\mathrm{x}$ & $\mathrm{x}$ \\
\hline & & P. echinulatum & DJSB 327 & Australia & Grass & & $\mathrm{x}$ & $\mathrm{x}$ \\
\hline & & P. flevoense & CBS 234.72 & Netherlands & Soil & & $\mathrm{x}$ & $\mathrm{x}$ \\
\hline & & P. graminicola & CBS 327.62 & Jamaica & Saccharum officinarum & & $\mathrm{x}$ & $\mathrm{x}$ \\
\hline & & Pythium group $\mathrm{F}$ & RD 55 & B.C., Canada & Phaseolus vulgaris & & $\mathrm{x}$ & $\mathrm{x}$ \\
\hline & & Pythium group $\mathrm{F}$ & RD 49 & B.C., Canada & Phaseolus vulgaris & & & $\mathrm{x}$ \\
\hline & & Pythium group $\mathrm{F}$ & $\mathrm{RD}$ & NA & NA & & & $\mathrm{x}$ \\
\hline & & Pythium group $\mathrm{G}$ & CAL 1478 & B.C., Canada & Phaseolus vulgaris & & $\mathrm{x}$ & $\mathrm{x}$ \\
\hline & & Pythium group $\mathrm{G}$ & RD 37 & B.C., Canada & Soil & $\mathrm{x}$ & & $\mathrm{x}$ \\
\hline & & Pythium group $\mathrm{G}$ & RD 51 & B.C., Canada & Soil & & & $\mathrm{x}$ \\
\hline & & P. helicoides & CBS 286.31 & U.S.A. & Phaseolus vulgaris & & $\mathrm{x}$ & $\mathrm{x}$ \\
\hline & & P. heterothallicum & CBS 450.67 & Canada & Sambucus sp. & $\mathrm{x}$ & & $\mathrm{x}$ \\
\hline & & P. heterothallicum & CBS 451.67 & Canada & Sambucus sp. & $\mathrm{x}$ & $\mathrm{x}$ & $\mathrm{x}$ \\
\hline & & P. hypogynum & IMI 242092 & U.K. & Petroselinum crispum & & & $\mathrm{x}$ \\
\hline & & P. hypogynum & DJSB 393 & Qué., Canada & Chenopodium album & $\mathrm{x}$ & & $\mathrm{x}$ \\
\hline & & P. intermedium & CAL 1217 & AK, U.S.A. & Water baiting & $\mathrm{x}$ & $\mathrm{x}$ & $\mathrm{x}$ \\
\hline & & P. intermedium & CBS 266.38 & Netherlands & Agrostis sp. & & & $\mathrm{x}$ \\
\hline & & P. irregulare & CBS 250.28 & Netherlands & Phaseolus vulgaris & $\mathrm{x}$ & $\mathrm{x}$ & $\mathrm{x}$ \\
\hline & & P. iwayamai & CBS 156.64 & Australia & Pinus sp. & $\mathrm{x}$ & & $\mathrm{x}$ \\
\hline & & P. iwayamai & CBS 697.83 & Japan & Triticum sp. & & $\mathrm{x}$ & $\mathrm{x}$ \\
\hline & & P. macrosporum & DJSB 492 & Netherlands & Flower bulb & & $\mathrm{x}$ & $\mathrm{x}$ \\
\hline & & P. mamillatum & DJSB 324 & India & Carthamus tinctorius & & & $\mathrm{x}$ \\
\hline & & P. mamillatum & CBS 251.28 & Netherlands & Beta vulgaris & & & $\mathrm{x}$ \\
\hline & & P. mamillatum & DJSB 326 & Australia & Malus pumila & & & $\mathrm{x}$ \\
\hline & & P. mamillatum & DJSB 765 & B.C., Canada & Cucumber & & $\mathrm{x}$ & $\mathrm{x}$ \\
\hline & & P. multisporum & CBS 470.50 & U.S.A. & Soil & $\mathrm{x}$ & $\mathrm{x}$ & $\mathrm{x}$ \\
\hline & & P. myriotylum & CBS 254.70 & Israel & Arachis hypogaea & & $\mathrm{x}$ & $\mathrm{x}$ \\
\hline & & P. okanoganense & CBS 315.81 & U.S.A. & Triticum aestivum & $\mathrm{x}$ & $\mathrm{x}$ & $\mathrm{x}$ \\
\hline & & P. oligandrum & CBS 382.34 & U.K. & Viola sp. & $\mathrm{x}$ & $\mathrm{x}$ & $\mathrm{x}$ \\
\hline & & P. oligandrum & ZGA & NC, U.S.A. & Turfgrass & & & $\mathrm{x}$ \\
\hline & & P. oligandrum & DJSB 262 & Ont., Canada & Pisum sativum & & & $\mathrm{x}$ \\
\hline
\end{tabular}

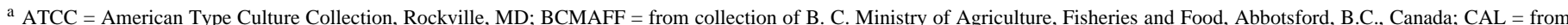
collection of C. A. Lévesque; CBS = Centraalbureau voor Schimmelcultures, Baarn, Netherlands; DJSB = from collection of Donald J. S. Barr, Eastern Cereal and Oilseed Research Centre, Ottawa, Ontario, Canada; DMR = DNA provided by D. M. Rochon, Agriculture and Agri-Food Canada, Summerland, B.C., Canada; FLC = from collection of F. L. Caruso, Cranberry Experimental Station, East Wareham, MA; FNM = from collection of F. N. Martin, USDA-ARS, Salinas, CA; IMI = International Mycological Institute, Surrey, England; $\mathrm{MJD}=$ from collection of M. J. Drilias, University of Wisconsin, WI; NRRL = Northern Regional Research Laboratory, USDA, Peoria, IL; PBH = from collection of P. B. Hamm, Oregon State University, Hermiston, OR; RD = from collection of Rolando Descalzo, IG MicroMed Environmentals, Richmond, B.C., Canada; WC = from collection of W. Chen, Illinois Natural History Survey, Champaign, IL;ZGA = strains provided for Pythium identification workshop organized by Z. G. Abad, North Carolina State University, Raleigh.

${ }^{b}$ Isolates that had their amplification products blotted on membranes shown in Figure 1.

c Isolates used for hybridization that are shown in Figures 3-6.

d Isolates tested by reverse dot blot hybridization with oligonucleotides.

e Information not available. 


\begin{tabular}{|c|c|c|c|c|c|c|c|c|}
\hline Phylum & Order & Species & Culture $^{\mathrm{a}}$ & Origin & Host or substrate & Fig. $1^{\text {b }}$ & $\begin{array}{l}\text { Figs. } \\
3-6^{c}\end{array}$ & $\begin{array}{l}\text { RDBH } \\
\text { tested }^{\text {d }}\end{array}$ \\
\hline & & P. paroecandrum & CBS 157.64 & Australia & Soil & $\mathrm{x}$ & $\mathrm{x}$ & $\mathrm{x}$ \\
\hline & & P.periilum & ZGA & NC, U.S.A. & Turfgrass & & $\mathrm{x}$ & $\mathrm{x}$ \\
\hline & & $P$. pleroticum & DJSB 257 & Ont., Canada & Pisum sativum & & $\mathrm{x}$ & $\mathrm{x}$ \\
\hline & & P. polymastum & DJSB 494 & Netherlands & Lectuca sativa & & $\mathrm{x}$ & $\mathrm{x}$ \\
\hline & & P. pulchrum & ZGA & NC, U.S.A. & Turfgrass & & $\mathrm{x}$ & $\mathrm{x}$ \\
\hline & & P. pyrilobum & CBS 158.64 & Australia & Pinus radiata & $\mathrm{x}$ & $\mathrm{x}$ & $\mathrm{x}$ \\
\hline & & $P$. rostratum & CBS 172.68 & U.K. & Medicago sativa & $\mathrm{x}$ & & $\mathrm{x}$ \\
\hline & & P. rostratum & CBS 533.74 & Netherlands & Soil & & $\mathrm{x}$ & $\mathrm{x}$ \\
\hline & & P. salpingophorum & DJSB 627 & Alb., Canada & Brassica napus & & & $\mathrm{x}$ \\
\hline & & P. salpingophorum & CBS 471.50 & Germany & Lupinus sp. & & & $\mathrm{x}$ \\
\hline & & P. salpingophorum & DJSB 897 & B.C., Canada & Turfgrass & & & $\mathrm{x}$ \\
\hline & & P. salpingophorum & DJSB 887 & Man., Canada & Triticum aestivum & & & $\mathrm{x}$ \\
\hline & & Pythium unknown & BCMAFF 93-224A & B.C., Canada & Rubus idaeus & & & $\mathrm{x}$ \\
\hline & & Pythium sp. & CAL 1493 & B.C., Canada & Vaccinium macrocarpon & & & $\mathrm{x}$ \\
\hline & & Pythium sp. & CAL 1495 & B.C., Canada & Vaccinium macrocarpon & & & $\mathrm{x}$ \\
\hline & & Pythium sp. & CAL 1497 & B.C., Canada & Vaccinium macrocarpon & & & $\mathrm{x}$ \\
\hline & & Pythium sp. & CAL 1499 & B.C., Canada & Vaccinium macrocarpon & & & $\mathrm{x}$ \\
\hline & & P. spinosum & ZGA & NC, U.S.A. & Turfgrass & & $\mathrm{x}$ & $\mathrm{x}$ \\
\hline & & P. spinosum & CBS 275.67 & Netherlands & Compost & & & $\mathrm{x}$ \\
\hline & & P. splendens & DJSB 435 & NJ, U.S.A. & Vaccinium corymbosum & $\mathrm{x}$ & & $\mathrm{x}$ \\
\hline & & P. splendens & CBS 462.48 & U.S.A. & NA & & $\mathrm{x}$ & $\mathrm{x}$ \\
\hline & & P. sulcatum & DJSB 195 & B.C., Canada & Daucus carota & $\mathrm{x}$ & $\mathrm{x}$ & $\mathrm{x}$ \\
\hline & & P. sulcatum & CBS 603.73 & WI, U.S.A. & Daucus carota & & $\mathrm{x}$ & $\mathrm{x}$ \\
\hline & & P. sylvaticum male & CAL 1446 & B.C., Canada & Triticum aestivum & $\mathrm{x}$ & & $\mathrm{x}$ \\
\hline & & P. sylvaticum female & CAL 1476 & B.C., Canada & Phaseolus vulgaris & $\mathrm{x}$ & & $\mathrm{x}$ \\
\hline & & P. sylvaticum female & CAL 1498 & B.C., Canada & Vaccinium macrocarpon & & & $\mathrm{x}$ \\
\hline & & P. sylvaticum & CBS 453.67 & TN, U.S.A. & Soil & & $\mathrm{x}$ & $\mathrm{x}$ \\
\hline & & P. tardicrescens & ZGA & NC, U.S.A. & Turfgrass & & $\mathrm{x}$ & $\mathrm{x}$ \\
\hline & & P. torulosum & CBS 316.33 & Netherlands & Grass root & & $\mathrm{x}$ & $\mathrm{x}$ \\
\hline & & P. ultimum var. ultimum & CBS 398.51 & Netherlands & Lepidum sativum & $\mathrm{x}$ & & \\
\hline & & P. ultimum var. ultimum & IMI 334959 & Peru & Solanum tuberosum & & & $\mathrm{x}$ \\
\hline & & P. ultimum var. ultimum & CBS 291.31 & NA & Dioscorea batatas & & & $\mathrm{x}$ \\
\hline & & P. ultimum var. ultimum & CBS 296.37 & U.K. & Pisum sativum & & $\mathrm{x}$ & $\mathrm{x}$ \\
\hline & & P. ultimum var. ultimum & CBS 488.86 & Poland & Malus sylvestris & & & $\mathrm{x}$ \\
\hline & & P. ultimum var. ultimum & CAL 1444 & B.C., Canada & Phaseolus vulgaris & & & $\mathrm{x}$ \\
\hline & & P. ultimum var. ultimum & CAL 1447 & B.C., Canada & Triticum aestivum & & & $\mathrm{x}$ \\
\hline & & P. ultimum var. ultimum & CAL 1491 & B.C., Canada & Vaccinium macrocarpon & & & $\mathrm{x}$ \\
\hline & & P. ultimum var. ultimum & CAL 1492 & B.C., Canada & Vaccinium macrocarpon & & & $\mathrm{x}$ \\
\hline & & P. ultimum var. ultimum & CAL 1494 & B.C., Canada & Vaccinium macrocarpon & & & $\mathrm{x}$ \\
\hline & & P. ultimum var. sporangiiferum & CBS 219.65 & U.S.A. & Chenopodium album & $\mathrm{x}$ & & $\mathrm{x}$ \\
\hline & & P. ultimum var. sporangiiferum & CBS 171.68 & U.K. & Medicago sativa & & $\mathrm{x}$ & $\mathrm{x}$ \\
\hline & & P. ultimum var. sporangiiferum & CBS 111.65 & Lebanon & Medicago sativa & & & $\mathrm{x}$ \\
\hline & & P. ultimum & RD & B.C., Canada & Soil & & & $\mathrm{x}$ \\
\hline & & P. undulatum & CAL 1232 & AK, U.S.A. & NA & $\mathrm{x}$ & & $\mathrm{x}$ \\
\hline & & P. undulatum & CBS 157.69 & AL, U.S.A. & Soil & & $\mathrm{x}$ & $\mathrm{x}$ \\
\hline & & P. vanterpoolii & DJSB 159 & Ont., Canada & Triticum aestivum & & $\mathrm{x}$ & $\mathrm{x}$ \\
\hline & & P. vexans & CBS 119.80 & Iran & Soil & & & $\mathrm{x}$ \\
\hline & & P. violae & CBS 159.64 & Australia & Soil & $\mathrm{x}$ & & $\mathrm{x}$ \\
\hline & & P. violae & CBS 178.86 & Netherlands & Daucus carota & $\mathrm{x}$ & & \\
\hline & & P. violae & CBS 159.64 & S. Australia & Soil & & $\mathrm{x}$ & $\mathrm{x}$ \\
\hline & & P. volutum & ZGA & NC, U.S.A. & Turfgrass & & $\mathrm{x}$ & $\mathrm{x}$ \\
\hline Oomycota & Peronosporales & Phytophthora cactorum & CAL 842 & U.K. & NA & & & $\mathrm{x}$ \\
\hline & & P. cactorum & DJSB 153 & N. S., Canada & Fragaria sp. & & $\mathrm{x}$ & $\mathrm{x}$ \\
\hline & & P. cambivora & CAL 841 & U.K. & Rubus idaeus & & $\mathrm{x}$ & $\mathrm{x}$ \\
\hline & & P. cambivora & PBH 150 & OR, U.S.A. & Abies sp. & & & $\mathrm{x}$ \\
\hline & & P. cinnamomi & FLC 9216 & MA, U.S.A. & Vaccinium macrocarpon & & & $\mathrm{x}$ \\
\hline & & P. cinnamomi & FLC 9217 & MA, U.S.A. & Vaccinium macrocarpon & & $\mathrm{x}$ & $\mathrm{x}$ \\
\hline & & P. cinnamomi $\mathrm{A} 2$ & DJSB 132 & U.K. & Erica sp. & & & $\mathrm{x}$ \\
\hline & & P. cinnamomi & MJD W.021 & MA, U.S.A. & Vaccinium macrocarpon & & & $\mathrm{x}$ \\
\hline & & P. cinnamomi & MJD W.244 & OR, U.S.A. & Vaccinium macrocarpon & & & $\mathrm{x}$ \\
\hline & & P. cinnamomi & MJD W.253 & NJ, U.S.A. & Vaccinium macrocarpon & & & $\mathrm{x}$ \\
\hline & & P. cinnamomi A2 & BCMAFF 94-1161 & B.C., Canada & Vaccinium corymbosum & & & $\mathrm{x}$ \\
\hline & & P. citricola & PBH 232 & MN, U.S.A. & Abies sp. & & $\mathrm{x}$ & $\mathrm{x}$ \\
\hline & & P. cryptogea & PBH 8819 & MA, U.S.A. & Vaccinium macrocarpon & & & $\mathrm{x}$ \\
\hline & & P. cryptogea & PBH 8823 & MA, U.S.A. & Vaccinium macrocarpon & & & $\mathrm{x}$ \\
\hline & & P. cryptogea & CBS 113.19 & NA & Lycopersicon esculentum & & & $\mathrm{x}$ \\
\hline & & P. cryptogea & MJD W.090 & WI, U.S.A. & Vaccinium macrocarpon & & & $\mathrm{x}$ \\
\hline & & P. cryptogea & MJD W.234 & MA, U.S.A. & Vaccinium macrocarpon & & & $\mathrm{x}$ \\
\hline & & P. cryptogea & MJD W.240 & OR, U.S.A. & Vaccinium macrocarpon & & $\mathrm{x}$ & $\mathrm{x}$ \\
\hline & & P. drechsleri & PBH 133 & B.C., Canada & Pseudotsuga menziensii & & $\mathrm{x}$ & $\mathrm{x}$ \\
\hline & & P. erythroseptica & PBH 577 & OR, U.S.A. & Solanum tuberosum & & $\mathrm{x}$ & $\mathrm{x}$ \\
\hline & & P. fragariae race $\mathrm{A} 4$ & CAL 1414 & N. S., Canada & Fragaria sp. & & & $\mathrm{x}$ \\
\hline & & P. fragariae var. rubi & CAL 1417 & U.K. & Rubus idaeus & & $\mathrm{x}$ & $\mathrm{x}$ \\
\hline & & P. infestans A2 & CAL 1424 & Canada & Solanum tuberosum & & & $\mathrm{x}$ \\
\hline & & P. infestans A1 & CAL 1426 & Canada & Solanum tuberosum & & $\mathrm{x}$ & $\mathrm{x}$ \\
\hline & & P. infestans A1 & CAL 1428 & Switzerland & Solanum tuberosum & & & $\mathrm{x}$ \\
\hline & & P. inflata & PBH 351 & NA & NA & & $\mathrm{x}$ & $\mathrm{x}$ \\
\hline & & P. lateralis & PBH 632 & OR, U.S.A. & Chamaecyparis lawsoniana & & & $\mathrm{x}$ \\
\hline & & P. lateralis & PBH 366 & CA, U.S.A. & Chamaecyparis lawsoniana & & & $\mathrm{x}$ \\
\hline & & P. lateralis & PBH 367 & NA/ & Chamaecyparis lawsoniana & & & $\mathrm{x}$ \\
\hline & & P. megasperma & FLC 8806 & MA, U.S.A. & Vaccinium macrocarpon & & $\mathrm{x}$ & $\mathrm{x}$ \\
\hline & & P. megasperma & FLC 8815 & MA, U.S.A. & Vaccinium macrocarpon & & & $\mathrm{x}$ \\
\hline & & P. megasperma & MJD W.088 & WI, U.S.A. & Vaccinium macrocarpon & & & $\mathrm{x}$ \\
\hline & & P. nicotianae & DJSB 235 & Ont., Canada & Poinsettia sp. & & $\mathrm{x}$ & $\mathrm{x}$ \\
\hline & & P. syringae & PBH 210 & NY, U.S.A. & Malus pumila & & $\mathrm{x}$ & $\mathrm{x}$ \\
\hline Zygomycota & Mucorales & Mortierella alpina & DAOM 175051 & Alb., Canada & Soil & & $\mathrm{x}$ & $\mathrm{x}$ \\
\hline & & Mortierella sp. & BCMAFF 94-1148 & B.C., Canada & Vaccinium macrocarpon & & & $\mathrm{x}$ \\
\hline & & Mortierella sp. & BCMAFF 94-1151 & B.C., Canada & Vaccinium macrocarpon & & & $\mathrm{x}$ \\
\hline & & Phycomyces nitens & ATCC 9984 & NA & NA & & $\mathrm{x}$ & $\mathrm{x}$ \\
\hline
\end{tabular}


under mineral oil and in water (11). This collection contains several genera of Oomycetes and a few of Chytridiomycetes, Zygomycetes, and Ascomycetes.

Fungal growth and DNA extraction. All isolates were grown according to previously published procedures (30). DNA was extracted from 5- to 10-day-old cultures as described previously (19). DNA pellets were resuspended in Tris-EDTA and diluted to

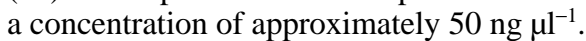

DNA amplification and labeling. For preparing membranes with immobilized ITS I region, approximately $10 \mathrm{ng}$ of total DNA template was amplified by PCR with primers ITS1 and ITS2 (43). The PCR reagents were obtained from a kit (Perkin Elmer, Norwalk, CT). A DNA thermocycler 480 (Perkin Elmer) was used for 39 cycles of 1 min at $94^{\circ} \mathrm{C}, 1 \mathrm{~min}$ at $60^{\circ} \mathrm{C}$, and $1 \mathrm{~min}$ at $72^{\circ} \mathrm{C}$ with a final 10 -min extension at $72^{\circ} \mathrm{C}$. For labeling, conditions were as described above, except that primers ITS1 and ITS4 were used with $16.7 \mu \mathrm{M}$ dTTP and $8.3 \mu \mathrm{M}$ alkaline labile DIG-dUTP (digoxigenin-11-dUTP; Boehringer Mannheim GmbH, Mannheim, Germany) instead of $200 \mu \mathrm{M}$ dTTP. The final product was ethanol-precipitated in $\mathrm{LiCl}$ according to the protocol from the manufacturer of DIG-dUTP.

Blotting entire ITS I. PCR products were gel purified with the Wizard PCR preps kit (Promega, Madison, WI) and quantified by using $\lambda$ DNA digested with ClaI to provide a size standard at $2.2 \mathrm{ng} \mathrm{\mu l}^{-1}$ for the smallest band of $290 \mathrm{bp}$, the average size of the PCR products obtained. The gels were photographed over a 300-nm UV light source. Densitometry of a scanned negative of the gel with the software NIH IMAGE (35) was done to generate a standard curve, to estimate the concentration of gel-purified PCR products, and to adjust to a final concentration of $12.5 \mathrm{ng} \mathrm{\mu l}^{-1}$. An aliquot of $2 \mu \mathrm{l}$ of DNA was mixed with $0.5 \mu \mathrm{l}$ of $2.5 \mathrm{~N} \mathrm{NaOH}$, and $0.2 \mu$ l of the mix was dotted ( $2 \mathrm{ng}$ per dot) $6 \mathrm{~mm}$ apart on a dry, positively charged nylon membrane (Boehringer). Membranes were baked at $120^{\circ} \mathrm{C}$ for $1 \mathrm{~h}$.

Hybridization with immobilized PCR products. Membranes were prehybridized in $20 \mathrm{ml}$ of hybridization solution (Boehringer) for a minimum of $1 \mathrm{~h}$ at one of the hybridization temperatures listed below. Between 2 and $10 \mathrm{ng}$ of DNA from the PCR reaction product was used as a probe for hybridization in 8 -ml volume. Overnight hybridization, a room-temperature wash in $2 \times \mathrm{SSC}(1 \times \mathrm{SSC}$ is $0.15 \mathrm{M} \mathrm{NaCl}$ plus $0.015 \mathrm{M}$ sodium citrate, $\mathrm{pH} 7.0$ ), and two final washes in $0.1 \times \mathrm{SSC}$ were done according to the procedure of Boehringer. Hybridizations and final washes were performed at 60 and $68^{\circ} \mathrm{C}, 60$ and $73^{\circ} \mathrm{C}, 68$ and $68^{\circ} \mathrm{C}, 68$ and $73^{\circ} \mathrm{C}, 68$ and $80^{\circ} \mathrm{C}, 68$ and $95^{\circ} \mathrm{C}, 72$ and $72^{\circ} \mathrm{C}, 72$ and $76^{\circ} \mathrm{C}$, 75 and $75^{\circ} \mathrm{C}, 75$ and $80^{\circ} \mathrm{C}, 75$ and $95^{\circ} \mathrm{C}, 80$ and $80^{\circ} \mathrm{C}$, and 80 and $95^{\circ} \mathrm{C}$, respectively. Digoxigenin was detected by chemiluminescence according to the protocol from the manufacturer by using 3-(2'spiroadamantane)-4-methoxy-4-(3"-phosphoryloxy)-phenyl-1,2dioxetane (Lumigen-PPD) with 15- to 60-min film exposure (XOmatic K; Kodak, Rochester, NY) on the day after the LumigenPPD was added. Hybridizations were done at least twice. Membranes were erased according to the procedure of Boehringer for alkaline-labile DIG-dUTP.

TABLE 2. Nucleotide sequences of oligonucleotides used for reverse dot blot

\begin{tabular}{ll}
\hline Specificity & Nucleotide sequence \\
\hline Oomycete & 5'-TGC GGA AGG ATC ATT ACC ACA C \\
Phytophthora spp. & 5'-TTC CAC GTG AAC CGT ATC AAC \\
Pythium acanthicum-92 & 5'-AAG ATT TGA GGC TGA ACG AA \\
Pythium acanthicum-132 & 5'-GAT GCG GAT TTG CTG ATG TTA \\
Pythium aphanidermatum & 5'-TTT TGG AGT ATA GAT CAG TAT TAG \\
& GTA AA \\
Pythium ultimum & 5'-TGC TGA CTC CCG TTC CAG TG \\
Phytophthora cinnamomi & 5'-CGT GGC GGG CCC TAT CAC TG \\
Positive control (ITS2) & 5'-GCT GCG TTC TTC ATC GAT GC \\
Positive control (ITS4) & 5 \\
\hline
\end{tabular}

${ }^{\text {a }}$ Forward version of primer from Lee and Taylor (27).

${ }^{\mathrm{b}}$ From White et al. (43).
DNA sequencing and oligonucleotide selection. Sequencing of ITS I for P. aphanidermatum (DJSB 444), P. ultimum (CBS 398.51), and $P$. acanthicum (CBS 377.34) isolates was performed with the AmpliTaq Dye Terminator Cycle Sequencing kit (Applied Biosystems, Foster City, CA) and a 373 automated sequencer
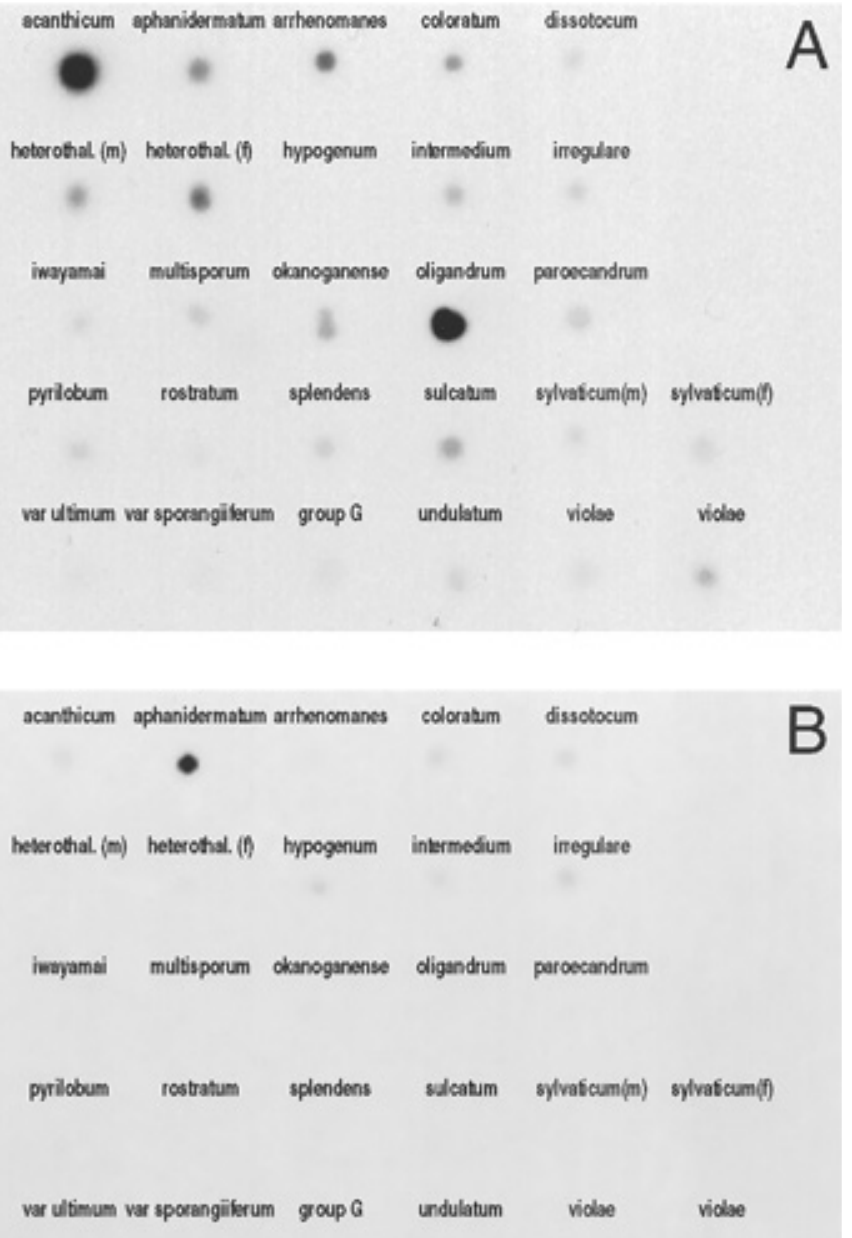

acanthicum aphanidermatum arthenomanes colorabum dissobocum

hobrothal. $(m)$ hoberothal. (f) hypogonum intormedium imegulare

imayama

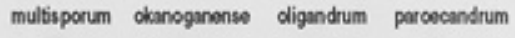

a

pyrilobum restratum splendens sulcatum sylvatcum(m) sylvatcum(f)

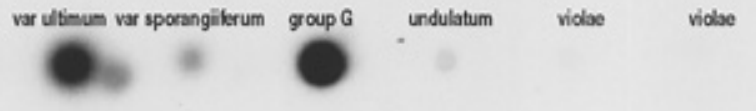

Fig. 1. Reverse dot blot hybridizations in which polymerase chain reaction (PCR)-amplified internal transcribed spacers (ITS) were blotted directly onto the nylon membranes. The isolates used to produce the blotted PCR products are identified in Table 1. PCR-amplified and labeled ITS regions of the following species were used as probes: A, Pythium acanthicum, CBS 377.34; B, $P$. aphanidermatum, CBS 118.80; and C, P. ultimum var. ultimum, CBS 398.51 . 
from the same manufacturer. Templates, prepared by PCR as described above with primers ITS1 and ITS4 (43), were purified with NucleotrapPCR (Macherey-Nagel, Düren, Germany) and used at $250 \mathrm{ng}$ per sequencing reaction with $3.2 \mathrm{pmol}$ of primers ITS1 or ITS 2 (43). Pythium and Phytophthora (26) sequences were aligned with GCG 7.0 (Genetic Computer Group, Madison, WI), and the software Oligo 4.0 (National Biosciences, Plymouth, $\mathrm{MN}$ ) was used in the design of the oligonucleotides.

Blotting oligonucleotides. Oligonucleotides listed in Table 2 were poly $(\mathrm{dT})$-tailed at the $3^{\prime}$ end and blotted according to the procedure of Kawasaki et al. (22). A control with the ITS I and ITS II regions amplified with the primer pair ITS5 and ITS4 (43) was also added by using $4 \mathrm{ng}$ total of an equal mix of amplified DNA of Gloeosporium sp., Phytophthora megasperma, Pythium heterothallicum, and Mortierella sp. The detection control dot contained $2 \mathrm{ng}$ of the same ITS region of Pythium ultimum that had been labeled by PCR with alkaline stable DIG-dUTP. These controls were blotted after heat denaturation. Membranes were irradiated by UV (Stratalinker 1800; Stratagene, San Diego, CA) to bind the DNA (22).

Hybridization with immobilized oligonucleotides. Membranes were prehybridized in $20 \mathrm{ml}$ of hybridization solution (Boehringer) for a minimum of $1 \mathrm{~h}$ at the hybridization temperature described below. From 50 to $100 \mathrm{ng}$ of labeled DNA from the PCR reaction was added to $8 \mathrm{ml}$ of hybridization buffer. Hybridization for a minimum of $2 \mathrm{~h}$, a room temperature wash in $2 \times \mathrm{SSC}$, and two final washes were done according to the procedure of Boehringer. A subset of isolates was used, and hybridizations and washes were done at $55,58,60$, and $65^{\circ} \mathrm{C}$ in addition to hybridization and final wash combinations of 45 and $58^{\circ} \mathrm{C}$ and 55 and $58^{\circ} \mathrm{C}$, respectively. Final washes were done subsequently in either $0.1,0.5,1.0$, or $2.0 \times \mathrm{SSC}$. Digoxigenin was detected as stated above. Membranes were erased according to the procedure of Boehringer for alkaline labile DIG-dUTP.

\section{RESULTS}

Reverse dot blot with immobilized PCR products. Differences among patterns of hybridization dots were obtained for a range of Pythium species, but identification to species level was difficult. Even under conditions of very high stringency, background and cross-hybridization reactions were observed. For example, hybridization at $80^{\circ} \mathrm{C}$ of reverse dot blot membranes with $P$. acanthicum DNA followed by washes at the same temperature with $0.1 \times$ SSC gave extensive cross-hybridization (Fig. 1A). Other species, such as $P$. irregulare, exhibited an even higher level of cross-hybridization (data not shown). Fungi such as $P$. aphanidermatum (Fig. 1B) and P. ultimum (Fig. 1C) that hybridized under the same conditions showed marginally lower levels of cross-hybridization. Similar results were observed when this approach was used with some Phytophthora species (data not shown).

Sequencing and oligonucleotide design. Sequences of the ITS I regions were determined for three different Pythium species (Fig. 2 ). Potential species-specific, genus-specific, and oomycete-specific primers were designed by using this alignment and that of Lee and Taylor (26). Selected oligonucleotides were tested by reverse dot blot (Table 2).

Reverse dot blots with immobilized oligonucleotides. The optimum conditions selected for hybridizations and washes were determined to be $55^{\circ} \mathrm{C}$ followed by final washes with $2.0 \times \mathrm{SSC}$. The oomycete oligonucleotide hybridized to seven different genera

\begin{tabular}{|c|c|c|c|c|c|c|}
\hline Consensus & TGAACCTGC & GGAAGGATCA & TTACCACACY & WWAAAAAACT & KTCCACGTGA & \\
\hline ultimum & $, \bullet, \bullet, \bullet$, & 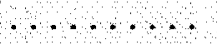 & $\ldots \ldots \ldots \mathrm{T}$ & TT ....... & $G \ldots \ldots$ & \\
\hline aphanider. & $\bullet$ & $\bullet \bullet . . . \bullet \bullet \bullet$ & $\ldots \ldots \ldots c$ & $\mathrm{AT} \ldots . .$. & T........ & \\
\hline acanthicum & &.. & $\ldots \mathrm{C}$ & TA....-. & T........ & \\
\hline Consensus & WRHA & AGTYYAGCGC & TGTGWCTGWG & CYGGTGTYKT & CATTKTYGGA & \\
\hline ultimum & $\ldots \mathrm{T} \ldots \mathrm{AGC}$ & $\ldots \mathrm{CT} \ldots$. & ...A..A. & . T.... TT. & $\ldots$ т.т. & \\
\hline aphanider. & . . . . -TGA. &.$--\mathrm{TC} .---$ & $\ldots-\mathrm{T} \ldots \mathrm{T}$ & $.-\cdots-. C-$ & $.-\ldots-. \mathrm{C}-.-$ & \\
\hline acanthicum & . C. . TAT. &.$--\mathrm{CT} .----$ & $\ldots-T \ldots T$. & $. \mathrm{C}-\cdots-. \mathrm{CG}$ & $.-\ldots \mathrm{G} . \mathrm{T}-\ldots$ & \\
\hline Consensus & CACTRGAAYK & KGAGTCAGCW & GRACGAAGGT & GGGCTGCTTA & ATTGTAGTCT & \\
\hline ultimum & $\ldots$.....CG & G.......A &. G... & -- &..---- & \\
\hline aphanider. & ---- G...-- &...$----- \mathrm{T}$ & .A. . & $\ldots$ & $\cdots$ & \\
\hline acanthicum &.$---\mathrm{A} .-. \mathrm{TT}$ & $\mathrm{T} \ldots \ldots \ldots$ & .A. & $\cdot---------$ & ----- . & \\
\hline Consensus & GTTGTMWTKY & AAGTKATGAY & GGAYTWGCYG & ATGAACTTTT & RTTTTWMAMA & \\
\hline ultimum & $\ldots \ldots A A \cdot G C$ & $\ldots \mathrm{T} \ldots \mathrm{T}$ & ..C.A.T. & & G....AA.-- & \\
\hline aphanider. & $\cdot---------$ & ---------- &.$------- \mathrm{C}$. &.$^{----}$ & A...TC.A. & \\
\hline acanthicum & $\ldots-\ldots$ & $--. \mathrm{G} . . .-\mathrm{C}$ & ..T.T.T. & & A. . . AA.C. & \\
\hline Consensus & CCYATT'PACY & TAAATACTGA & WCTATACTSY & RRRDACGAAA & GTYYWTGSTT & \\
\hline ultimum & $\ldots \mathrm{C}--\ldots \mathrm{C}$ & $\ldots \ldots$ & $\mathrm{T}-\ldots . . \mathrm{GT}$ & GGGG. . . & . ССТ..С. & \\
\hline aphanider & $\ldots C \ldots \ldots c$ & - . & T......CC & AAAA. & . TTA..G. & \\
\hline acanthicum & $\ldots T \cdot-\ldots T$ &.- . & A..... CC & GAAT $\ldots$. & . TTT..G. & \\
\hline Consensus & TTAMYMDWTA & ACAACTTTCA & GCAGTGGATG & TCTAGGCTCG & CGC & \\
\hline ultimum & ... CTAGA . & $., 1,-.$, & •....... & $\bullet-\bullet \cdot-\bullet$ & 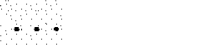 & \\
\hline ider. & ...АТСТА. & 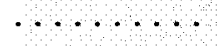 & $\bullet \bullet \bullet \bullet \bullet \bullet \bullet \bullet$ & $\bullet \bullet \bullet \cdot \bullet \bullet \bullet$ & $\bullet$ & \\
\hline thicum & $\ldots$. АСАAТ &...,$-\bullet$ & $\because$ & 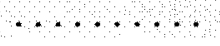 & $\bullet$ & \\
\hline
\end{tabular}

Fig. 2. Sequence alignment of the internal transcribed spacer I region of Pythium ultimum var. ultimum (CBS 398.51), P. aphanidermatum (CBS 118.80), and P. acanthicum (CBS 377.34). Gene-coding regions for the $18 \mathrm{~S}$ and 5.8S genes are shaded. Consensus nucleotides are identified as dots, and sequence gaps are shown as dashes. The sequences used to synthesize the oligonucleotides in this study are underlined. 
of that group but not to any of the other fungal genera tested (Fig. 3). It also hybridized to all Phytophthora and Pythium species tested (Figs. 4 and 5).

Several species were used to verify the genus specificity of the Phytophthora oligonucleotide. The Phytophthora species tested hybridized to the oligonucleotide, except $P$. nicotianae and $P$. citricola (Fig. 4). The intensity of the hybridization signal was lower with $P$. cactorum and $P$. infestans. Several isolates of $P$. cinnamomi were tested (Table 2), and all hybridized to the oligonucleotide designed for this species (Fig. 4).

Many isolates of the two varieties of $P$. ultimum were tested (Table 1), all of which hybridized to the oligonucleotide for $P$. ultimum, as shown in Figure 5. Isolates of Pythium group G also hybridized. None of the other species tested hybridized to this oligonucleotide (Fig. 5). All test isolates of $P$. acanthicum hybridized to the two oligonucleotides (92 and 132) designed for P. acanthicum.

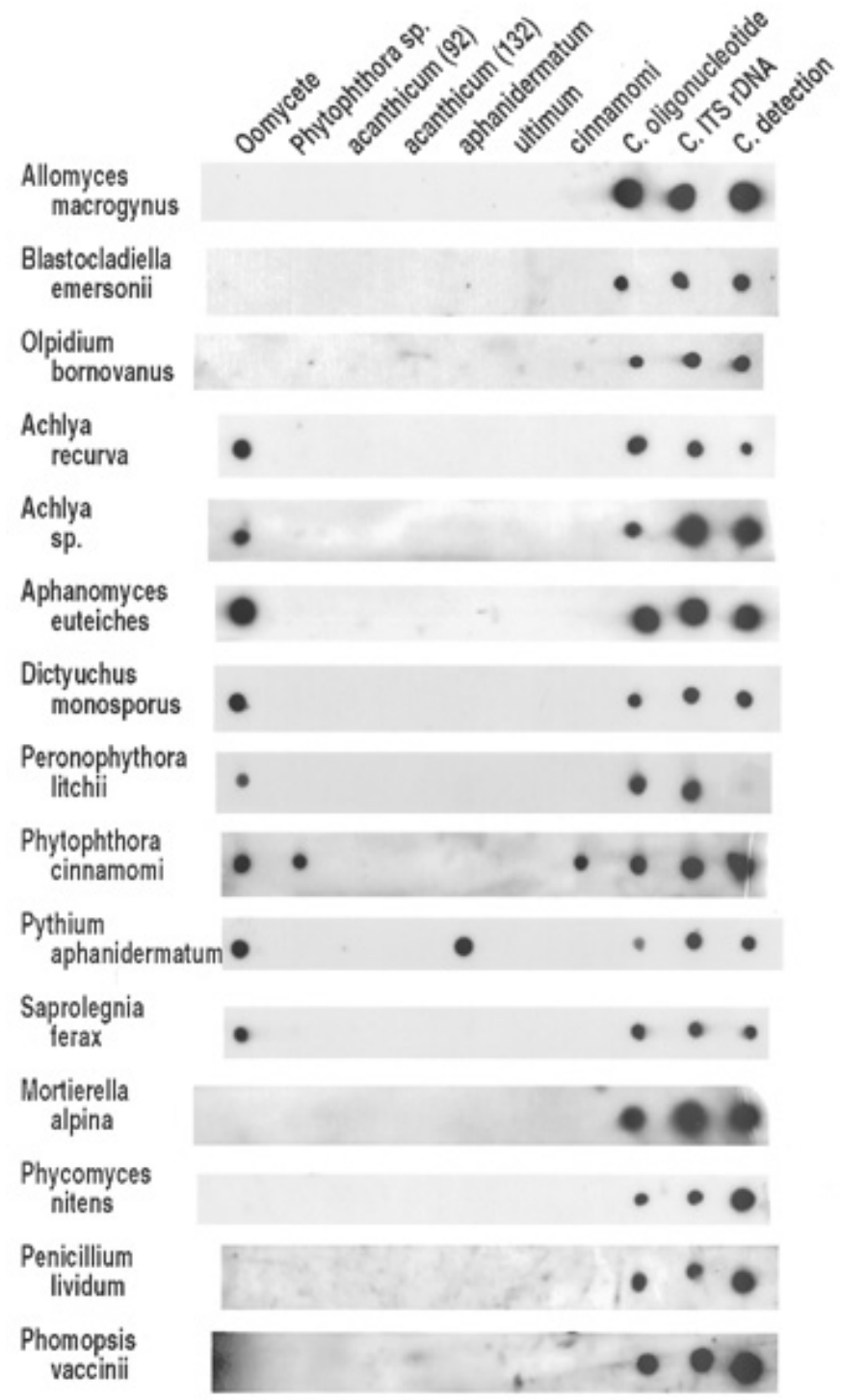

Fig. 3. Reverse dot blot hybridizations with immobilized specific oligonucleotides (listed at the top and in Table 2) to demonstrate the specificity of the oomycete and genus Phytophthora oligonucleotides (first two dots on the left of each membrane). The species listed on the left were used to make the probes for each hybridization (Table 1 has isolate numbers). Hybridizations and washes were performed at $55^{\circ} \mathrm{C}$. The three dots on the right are controls (C.): oligonucleotide $=$ universal ITS2 and ITS4 (Table 2); ITS rDNA = amplified and mixed ITS I from a wide range of genera; and detection = ITS I amplified and labeled with alkaline stable DIG-dUTP (digoxigenin-11-dUTP) (the membrane used for Pyrenophythora litchii was blotted at that location with an alkaline labile DIG-dUTP by mistake).
Oligonucleotide 132 also hybridized with $P$. oligandrum and $P$. acanthophoron, whereas the oligonucleotide 92 hybridized faintly to $P$. acanthophoron. All test isolates of $P$. aphanidermatum hybridized to the oligonucleotide designed for this species (Fig. 5). However, strong cross-hybridization was observed with $P$. deliense and $P$. hypogynum, and weaker reactions were observed with $P$. aristosporum and $P$. arrhenomanes (Fig. 5). Hybridization and washes done at $60^{\circ} \mathrm{C}$ showed that the $P$. deliense cross-reaction was still as strong as the reaction with $P$. aphanidermatum, while the others no longer cross-hybridized (Fig. 6). At this higher temperature, the universal oligonucleotide also did not hybridize.

The hybridization results were highly reproducible. Probes made from different PCR amplifications of the same isolates gave the same results with erased or newly blotted membranes. For selected isolates, the initial hybridization solution was reused with different membranes five consecutive times during a 4-month period. Results were highly consistent, but for each subsequent hybridization, film exposure had to be increased by a few minutes to achieve equivalent intensities.

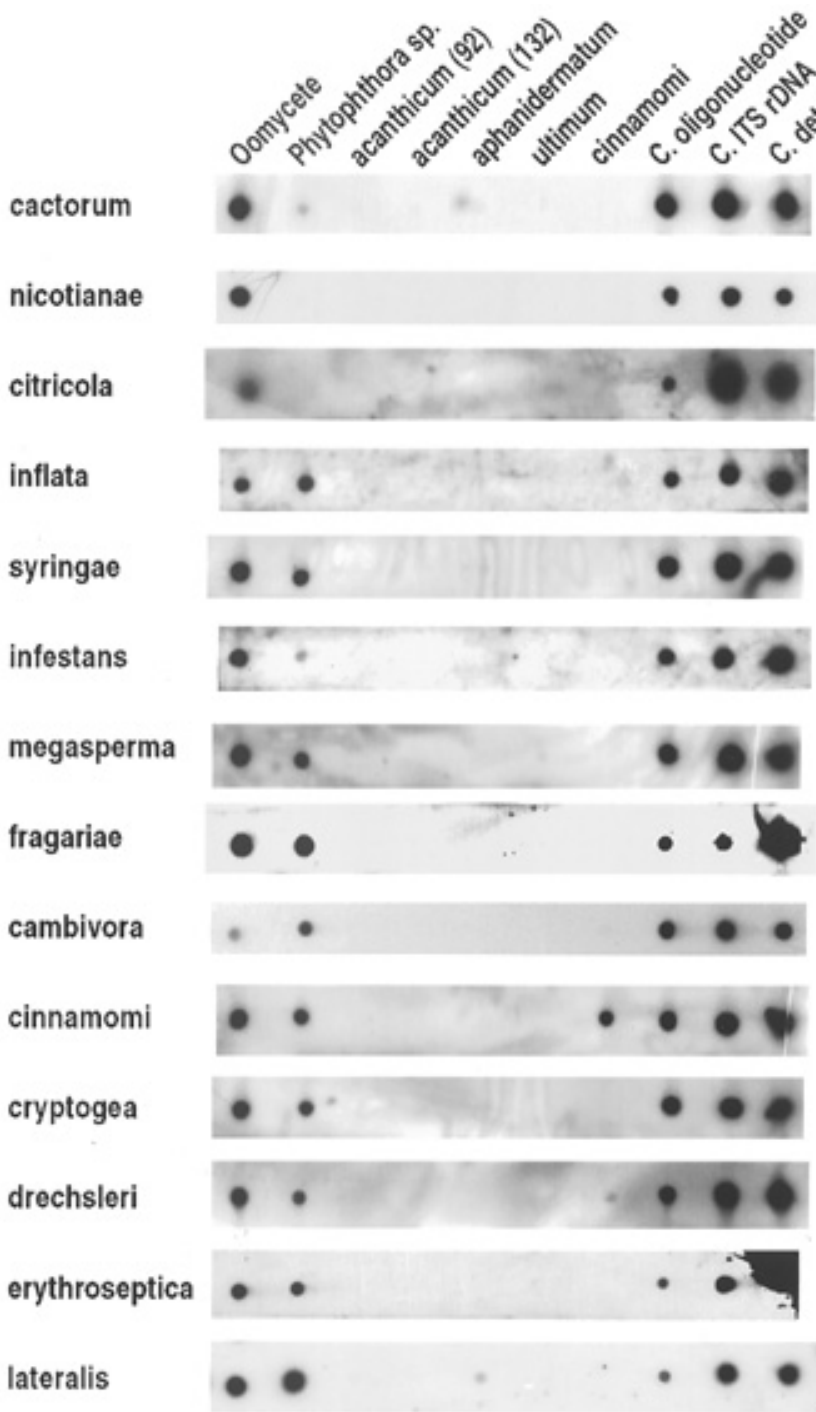

Fig. 4. Reverse dot blot hybridizations with immobilized specific oligonucleotides (listed at the top and in Table 2) to demonstrate the specificity of the genus Phytophthora and the P. cinnamomi oligonucleotides (second and seventh dots of each membrane). The Phytophthora species listed on the left were used to make the probes for each hybridization (Table 1 has isolate numbers). Hybridizations and washes were performed at $55^{\circ} \mathrm{C}$. The three dots on the right are controls (C.): oligonucleotide = universal ITS2 and ITS4 (Table 2); ITS rDNA = amplified and mixed ITS I from a wide range of genera; and detection = ITS I amplified and labeled with alkaline stable digoxigenin-11-dUTP. 


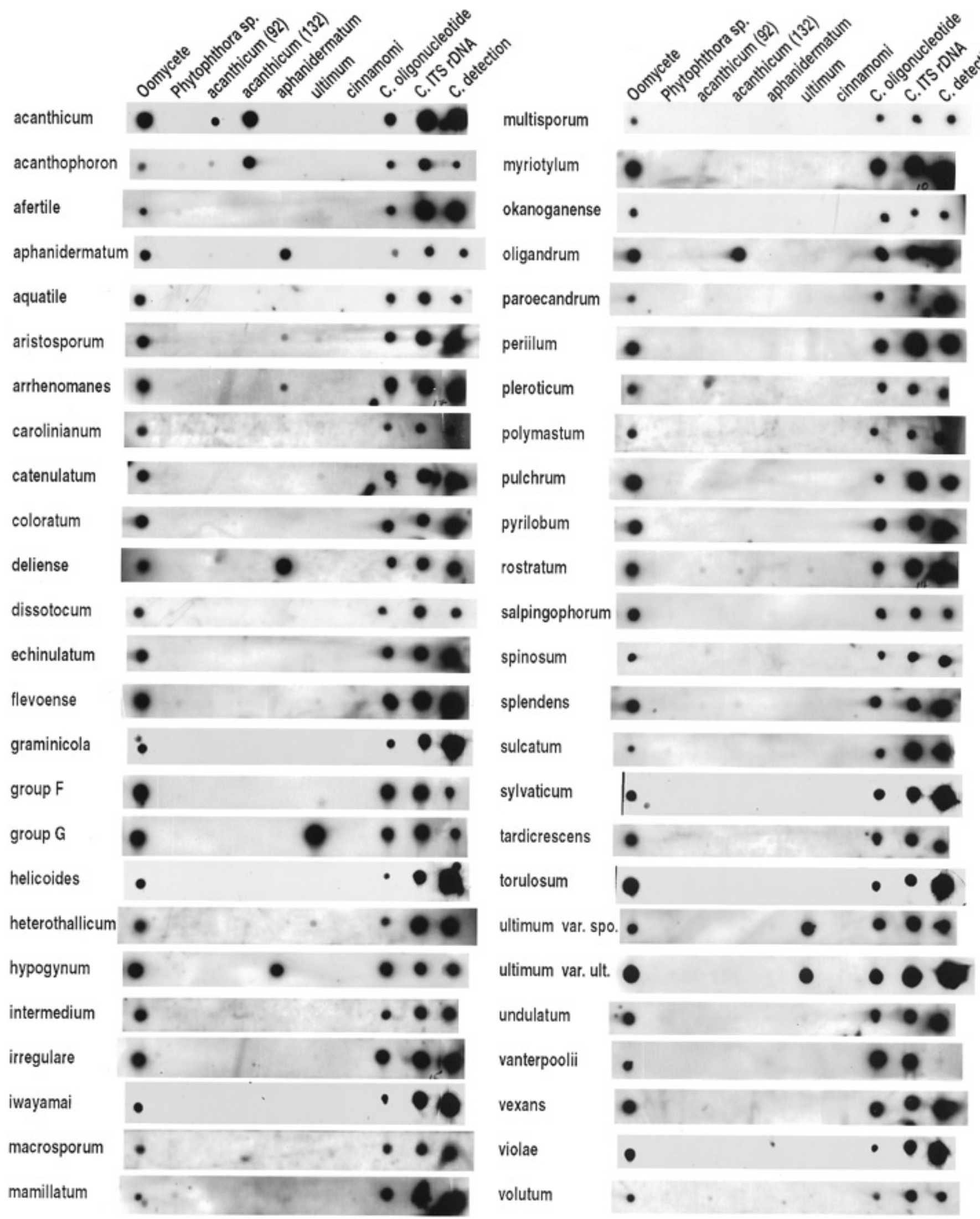

Fig. 5. Reverse dot blot hybridizations with immobilized specific oligonucleotides (listed at the top and in Table 2) to demonstrate the specificity of the Pythium acanthicum, P. aphanidermatum, and P. ultimum oligonucleotides. The Pythium species listed were used to make the probes for each hybridization (Table 1 has isolate numbers). Hybridizations and washes were performed at $55^{\circ} \mathrm{C}$. The three dots on the right are controls (C.): oligonucleotide $=$ universal ITS2 and ITS4 (Table 2); ITS rDNA = amplified and mixed ITS I from a wide range of genera; and detection = ITS I amplified and labeled with alkaline stable DIG-dUTP (digoxigenin-11-dUTP) (the membrane used for $P$. vanterpoolii was blotted at that location with an alkaline labile DIG-dUTP by mistake). 


\section{DISCUSSION}

Two variations of the reverse dot blot technology were tested to identify oomycetes. The reverse dot blot with the immobilized entire ITS I is quite simple to develop and shows potential for identifying some species when pure cultures are used. This approach is a logical continuation of previous work by Lévesque et al. (30), where it was shown that the entire ITS I of P. ultimum could be used as a species-specific probe in standard dot blot assay. Positive results for P. ultimum (Fig. 2C) in the reverse dot blot assay with entire ITS I support these earlier findings. However, the reverse dot blot technique must be amenable not only to the identification of pure cultures, but ultimately to the direct processing of environmental samples from sources such as spore traps, soil, roots, and water. Patterns observed in reverse dot blots designed with the entire ITS I may prove useful to fully or partially identify a pure culture but will not work with field samples that might contain a mixture of species. For this reason, the reverse dot blot approach with the entire ITS I was not pursued further. Klassen et al. (23) showed that the 5S ribosomal RNA gene spacer could be used as a species-specific hybridization probe. This spacer might lend itself better to conversion to the reverse dot blot technique with entire species-specific PCR products immobilized on membranes.

Reverse dot blot with immobilized oligonucleotides gave much less ambiguous results than reverse dot blot with immobilized PCR products. All the species targeted in this study were identified by the reverse dot blot assay. Work with the cystic fibrosis gene has shown that a single base mismatch is enough to design a mutation-specific oligonucleotide for reverse dot blot (22). This is potentially a problem if one wants to be certain that a given oligonucleotide covers the range of variation in a species. To minimize this possibility, the species-specific oligonucleotides in this study were tested against isolates from different continents.

The oomycete oligonucleotide hybridized to all oomycete species tested but not to other zoosporic or coenocytic fungi. However, before it can be concluded that this is an oomycete-specific probe, its hybridization capability has to be confirmed in tests with representatives of groups that were not included in this study, such as the Leptomitales or downy mildews. The phylum Oomycota is now classified in the kingdom Stramenopila (2). Available ITS sequence data of stramenopiles $(21,39)$ that do not belong to Oomycetes show as much dissimilarity with the oomycete-specific oligonucleotide sequence as does the genus Penicillium (32),

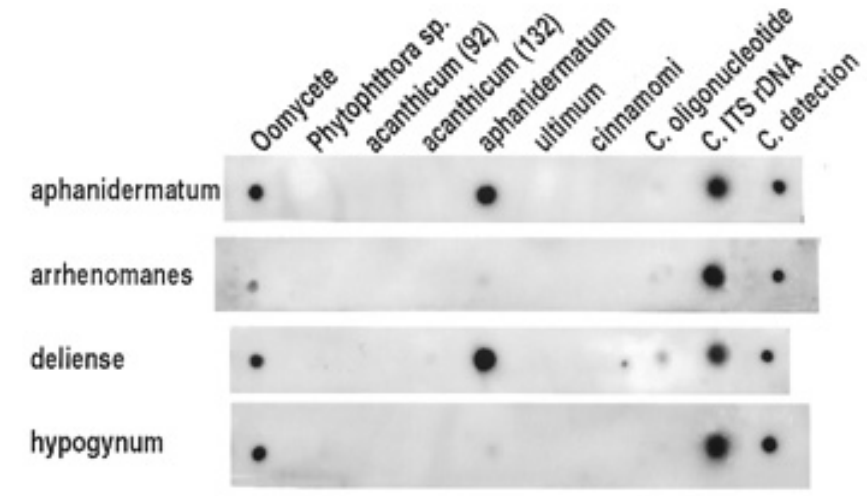

Fig. 6. Reverse dot blot hybridizations with immobilized specific oligonucleotides (listed at the top and in Table 2) to demonstrate the specificity of the Pythium aphanidermatum oligonucleotide. The Pythium species listed on the left were used to make the probes for each hybridization (Table 1 has isolate numbers). Hybridizations and washes were performed at $60^{\circ} \mathrm{C}$. The three dots on the right are controls (C.): oligonucleotide $=$ universal ITS2 and ITS4 (Table 2); ITS rDNA= amplified and mixed ITS I from a wide range of genera; and detection = ITS I amplified and labeled with alkaline stable digoxigenin-11-dUTP. which did not hybridize at all with the oomycete oligonucleotide. On the basis of the sequence differences, it is unlikely that the oomycete oligonucleotide would have hybridized to other stramenopiles.

The oligonucleotide developed for the genus Phytophthora hybridized with most Phytophthora species tested. It is noteworthy that this oligonucleotide reacted strongly only with Phytophthora species with nonpapillate sporangia, except $P$. inflata, which has semipapillate sporangia. The oligonucleotide for the genus Phytophthora developed by Lee et al. (27) was hybridized by reverse dot blot, but its melting temperature was too low for the final conditions adopted (data not shown). Sequence extension of this oligonucleotide was not possible because of sequence heterology among species of Phytophthora. This oligonucleotide was located at the $3^{\prime}$ end of the ITS I spacer, whereas the one designed for the present study was located at the $5^{\prime}$ end. $P$. cactorum and $P$. infestans consistently gave the same faint hybridization reaction with the Phytophthora genus oligonucleotide developed for this study. The sequences of $P$. infestans published by Cooke et al. (12) after the present study was completed showed that our genus Phytophthora oligonucleotide had one mismatch six bases from the $5^{\prime}$ end. The $P$. cactorum sequence from Cooke et al. (12) showed the same mismatch as well as another mismatch at the final base of the $5^{\prime}$ end. The genus Phytophthora oligonucleotide from Lee et al. (27) had two consecutive mismatches at the far $3^{\prime}$ end for $P$. cactorum but still hybridized to this species in standard dot blot assay. Likewise, the additional mismatch at the far $5^{\prime}$ end for $P$. cactorum did not appear to decrease the hybridization signal compared with that observed with $P$. infestans, which had only one mismatch closer to the middle (Fig. 4). These observations would support the conclusion by Kawasaki et al. (22) that mismatches in the middle of an oligonucleotide are more destabilizing than those at the $5^{\prime}$ or $3^{\prime}$ end.

All isolates of $P$. ultimum hybridized to the oligonucleotide developed for this species, including isolates from $P$. ultimum var. sporangiiferum and Pythium "group G." This was consistent with standard dot blot results obtained previously (30). The results suggest that the isolates identified as Pythium group G actually represent sexually sterile $P$. ultimum isolates (37). Using three different molecular techniques, Francis et al. (15) concluded that the two varieties of $P$. ultimum were not genetically distinct. Using $5 \mathrm{~S}$ ribosomal RNA gene spacer probes, Klassen et al. (23) found that there were two molecular groups within $P$. ultimum but that these groups did not correlate well with the variety classification (i.e., half the $P$. ultimum var. sporangiiferum isolates were similar to $P$. ultimum var. ultimum for molecular markers). Cross-reactions between the varieties were also observed on overexposed blots (23). Our partial reverse dot blot results with amplified PCR fragments also support the fact that there are at least two molecular groups for P. ultimum (Fig. 1C).

For identification of $P$. acanthicum, oligonucleotide 132 reacted strongly with $P$. acanthicum, $P$. acanthophoron, and $P$. oligandrum, while oligonucleotide 92 reacted only to $P$. acanthicum and $P$. acanthophoron. This combination of oligonucleotides can be used to identify either $P$. oligandrum or $P$. acanthicum. These results are consistent with the fact that $P$. oligandrum shares significant characteristics with $P$. acanthicum: both have ornamented oogonia and contiguous sporangia (40). The hybridization reactions of $P$. acanthophoron were more like those of $P$. acanthicum than $P$. oligandrum, although hybridization with oligonucleotide 92 was faint. Morphologically, $P$. acanthophoron is very similar to $P$. acanthicum, except that it lacks the ability to produce sporangia in culture (40).

The oligonucleotide developed for $P$. aphanidermatum crosshybridized with some other Pythium species at $55^{\circ} \mathrm{C}$, but when the assay temperature was increased to $60^{\circ} \mathrm{C}$, cross-hybridization with only $P$. deliense was observed. In the taxonomic treatise of Pythium species by Van der Plaats-Niterink (40), these two spe- 
cies are separated mainly by the curvature of the oogonial stalk in $P$. deliense. On the basis of present molecular and morphological evidence, it appears that the taxonomic status of these two species needs further clarification. The best results for identification of $P$. aphanidermatum were obtained at a higher temperature than that used for the other oligonucleotides, which poses a technical problem. However, we demonstrated that it is possible to obtain the same results as those shown in Figures 5 and 6 from a single hybridization done at $55^{\circ} \mathrm{C}$ (data not shown). After initial washes at $55^{\circ} \mathrm{C}$ followed by detection, more stringent washes and another detection can be performed on the same membrane.

One of the main advantages of the reverse dot blot technique is the potential for the integration of results from several other studies into a single assay. This is exemplified by the rapid expansion of the cystic fibrosis mutation screening assay (42). With the species-specific oligonucleotide for Phytophthora cinnamomi from Lee et al. (27), we have also demonstrated that the results from standard dot blot with oligonucleotides can be directly applicable to reverse dot blot. However, as shown with the example of the oligonucleotide for all Phytophthora species from Lee et al. (27), it will not always be possible to use oligonucleotide data directly from the work of others. As its name indicates, the reverse dot blot can use immobilized standard dot blot probes. Normally, in a standard dot blot assay, each of these oligonucleotide probes would be used at its own optimized hybridization condition. However, in a reverse dot blot assay, the oligonucleotide probes must all be used under the same conditions. The necessity for standardization of the melting temperatures in the design of all the oligonucleotides continues to be the principal technical difficulty and the main reason that species-specific oligonucleotides, used successfully in standard dot blot, have to be modified before use with this new technology. Equations for estimating melting temperature do not always predict accurately the optimal hybridization condition (27). Furthermore, the optimal standard dot blot hybridization condition for a given oligonucleotide may not match the optimal condition required for reverse dot blot (data not shown). Initial screening of oligonucleotides by standard dot blot was abandoned for this reason. The hybridization kinetics of the standard dot blot are probably quite different from those of a reverse dot blot. In the former, a short, free-floating molecule must bind and stay attached to a long, immobilized one; and in the latter, it is the short molecule that is immobilized to bind to the free, long ones. With the current increased usage of reverse dot blot in the medical field, it is hoped that more will become known about the theoretical melting point to facilitate the design of oligonucleotides for this technology.

We have demonstrated that the reverse dot blot technology can be used for identification of some oomycete species. There are numerous possibilities for expanding and refining this technology further. We have used only one pair of PCR primers to generate the labeled ITS region. Reverse dot blot has been used by labeling entire bacterial genomes (24) or by using several pairs of primers in a multiplex PCR reaction (22). As the GenBank database increases (5) and as insightful interpretations of the data allow updates of the classification, integration of more organisms into identification systems should become possible. For example, if sets of species-specific oligonucleotides from mitochondrial and nuclear DNA exist for a given group of fungal species, it would be possible to have a reverse dot blot assay that would simultaneously identify and validate a given isolate with these two very different sets of oligonucleotides. Primers targeting genes for avirulence or fungicide tolerance with nested specific oligonucleotides could also be incorporated in a reverse dot blot assay to go beyond species identification. Existing technologies can already overcome the physical limitations related to the number of specific oligonucleotides that can be blotted on a single membrane. More than one million different oligonucleotides have been synthesized directly on a silicon surface (31). The "lab in a micro- chip" design, being pursued by several companies, will drastically speed up sample processing for hybridization to oligonucleotide arrays and is likely to reduce cost as well (34). Since the first paper in 1989 describing hybridization to immobilized arrays of oligonucleotides (36), the number of papers in the medical field has almost doubled every year, reaching 30 in 1995. The majority of these papers describe detection of genetic disorders, but there is an increasing number of papers that focus on detection and identification of pathogenic bacteria or viruses $(1,20)$. With more complex arrays, the reverse dot blot technology could be useful for routine identification of fungi, diagnosis of plant diseases, and detection of fungi in soil or spore traps. The opportunities for integrated disease management arising from the applications of new detection technologies were recently reviewed (28).

\section{ACKNOWLEDGMENTS}

We thank C. Burton and Q. Wang for technical assistance, D. Barr and B. Pepin for helpful discussions, L. Ward for suggestions, and people listed in Table 1 for providing isolates. This work was supported partly by a grant from Energy Mines and Resources Canada.

\section{LITERATURE CITED}

1. Adachi, A., Kiyono, T., Hayashi, Y., Ohashi, M., and Ishibashi, M. 1996. Detection of human papillomavirus (HPV) type 47 DNA in malignant lesions from epidermodysplasia verruciformis by protocols for precise typing of related HPV DNAs. J. Clin. Microbiol. 34:369-375.

2. Alexopoulos, C. J., Mims, C. W., and Blackwell, M. 1996. Introductory Mycology. 4th ed. John Wiley \& Sons, New York.

3. Audy, P., Braat, C. E., Saindon, G., Huang, H. C., and Laroche, A. 1996. A rapid and sensitive PCR-based assay for concurrent detection of bacteria causing common and halo blights in bean seeds. Phytopathology 86:361-366.

4. Barr, D. J. S., Warwick, S. I., and Desaulniers, N. L. 1996. Isozyme variation, morphology, and growth response to temperature in Pythium ultimum. Can. J. Bot. 74:753-761.

5. Benson, D. A., Boguski, M., Lipman, D. J., and Ostell, J. 1996. GenBank. Nucleic Acids Res. 24:1-5.

6. Brasier, C. M. 1983. Problems and prospects in Phytophthora research. Pages 351-364 in: Phytophthora, Its Biology, Taxonomy, Ecology, and Pathology. D. C. Erwin, S. Bartnicki-Garcia, and P. H. Tsao, eds. American Phytopathological Society, St. Paul, MN.

7. Bruns, T. D., White, T. J., and Taylor, J. W. 1991. Fungal molecular systematics. Annu. Rev. Ecol. Syst. 22:525-564.

8. Chen, W. 1992. Restriction fragment length polymorphism in enzymatically amplified ribosomal DNAs of three heterothallic Pythium species. Phytopathology 82:1467-1472.

9. Chen, W., Hoy, J. W., and Schneider, R. W. 1991. Comparisons of soluble proteins and isozymes for seven Pythium species and applications of the biochemical data to Pythium systematics. Mycol. Res. 95:548-555.

10. Chen, W., Hoy, J. W., and Schneider, R. W. 1992. Species-specific polymorphism in transcribed ribosomal DNA of five Pythium species. Exp. Mycol. 16:22-34.

11. Commonwealth Mycological Institute. 1983. Plant Pathologist Pocketbook. 2nd ed. C.A.B. International, Kew, England.

12. Cooke, D. E. L., Kennedy, D. M., Guy, D. C., Russell, J., Unkles, S. E., and Duncan, J. M. 1996. Relatedness of group I species of Phytophthora as assessed by randomly amplified polymorphic DNA (RAPDs) and sequences of ribosomal DNA. Mycol. Res. 100:297-303.

13. Dick, M. W., ed. 1990. Keys to Pythium. M. W. Dick, Reading, England.

14. Erwin, D. C. 1983. Variability within and among species of Phytophthora. Pages 149-165 in: Phytophthora, Its Biology, Taxonomy, Ecology, and Pathology. D. C. Erwin, S. Bartnicki-Garcia, and P. H. Tsao, eds. American Phytopathological Society, St. Paul, MN.

15. Francis, D. M., Gehlen, M. F., and St. Clair, D. A. 1994. Genetic variation in homothallic and hyphal swelling isolates of Pythium ultimum var. ultimum and P. ultimum var. sporangiiferum. Mol. Plant-Microbe Interact. 7:766-775

16. Goodwin, P. H., Kirkpatrick, B. C., and Duniway, J. M. 1989. Cloned DNA probes for identification of Phytophthora parasitica. Phytopathology 79:716-721.

17. Goodwin, P. H., Kirkpatrick, B. C., and Duniway, J. M. 1990. Identification of Phytophthora citrophthora with cloned DNA probes. Appl. Environ. Microbiol. 56:669-674.

18. Hamelin, R. C., Bérubé, P., Gignac, M., and Bourassa, M. 1996. Identifi- 
cation of root rot fungi in nursery seedlings by nested multiplex PCR. Appl. Environ. Microbiol. 62:4026-4031.

19. Harlton, C. E., Lévesque, C. A., and Punja, Z. K. 1995. Genetic diversity in Sclerotium (Athelia) rolfsii and related species. Phytopathology 85: 1269-1281.

20. Kaufhold, A., Podbielski, A., Baumgarten, G., Blokpoel, M., Top, J., and Schouls, L. 1994. Rapid typing of group A streptococci by the use of DNA amplification and non-radioactive allele-specific oligonucleotide probes. FEMS Microbiol. Lett. 119:19-25.

21. Kawai, H., Muto, H., Fuji, T., and Kato, A. 1995. A linked 5S rRNA gene in Scytosiphon lomentaria. J. Phycol. 31:306-311.

22. Kawasaki, E. S., Saiki, R., and Erlich, H. 1993. Genetic analysis using polymerase chain reaction-amplified DNA and immobilized oligonucleotide probes: Reverse dot blot typing. Meth. Enzymol. 218:369-381.

23. Klassen, G. R., Balcerzak, M., and de Cock, A. W. A. M. 1996. 5S ribosomal RNA gene spacers as species-specific probes for eight species of Pythium. Phytopathology 86:581-587.

24. Kuhnert, P., Hacker, J., Muhldorfer, I., Burnens, A. P., Nicolet, J., and Frey, J. 1997. Detection system for Escherichia coli-specific virulence genes: Absence of virulence determinants in B and C strains. Appl. Environ. Microbiol. 63:703-709.

25. Kurtzman, C. P. 1989. Impact of nucleic acid comparisons on systematic mycology. Bot. J. Linn. Soc. 99:3-10.

26. Lee, S. B., and Taylor, J. W. 1992. Phylogeny of five fungus-like protoctistan Phytophthora spp., inferred from the internal transcribed spacers of ribosomal DNA. Mol. Biol. Evol. 9:636-653.

27. Lee, S. B., White, T. J., and Taylor, J. W. 1993. Detection of Phytophthora species by oligonucleotide hybridization to amplified ribosomal DNA spacers. Phytopathology 83:177-181.

28. Lévesque, C. A. 1997. Molecular detection tools in integrated disease management: Overcoming current limitations. Phytoparasitica 25:3-7.

29. Lévesque, C. A., Beckenbach, K., Baillie, D. L., and Rahe, J. E. 1993. Host specificity, pathogenicity, and restriction fragment length polymorphisms of isolates of two Pythium spp. that colonize glyphosate-treated plants. Mycol. Res. 97:307-312.

30. Lévesque, C. A., Vrain, T. C., and De Boer, S. H. 1994. Development of a species-specific probe for Pythium ultimum using amplified ribosomal DNA. Phytopathology 84:474-478.

31. Lipshutz, R. J., Morris, D., Chee, M., Hubbell, E., Kozal, M. J., Shah, N., Shen, N., Yang, R., and Fodor, S. P. A. 1995. Using oligonucleotide probe arrays to access genetic diversity. BioTechniques 19:442-447.
32. LoBuglio, K. F., Pitt, J. I., and Taylor, J. W. 1993. Phylogenetic analysis of two ribosomal DNA regions indicates multiple independent losses of a sexual Talaromyces state among asexual Penicillium species in subgenus Biverticillium. Mycologia 85:592-604.

33. McManus, P. S., and Jones, A. L. 1995. Detection of Erwinia amylovora by nested PCR and PCR-dot blot and reverse-blot hybridizations. Phytopathology 85:618-623.

34. O'Donnell-Maloney, M. J., and Little, D. P. 1996. Microfabrication and array technologies for DNA sequencing and diagnostics. Genet. Anal. 13:151-157.

35. Rasband, W. 1993. NIH IMAGE, V. Version 1.51. National Institutes of Health, Bethesda, MD.

36. Saiki, R. K., Walsh, P. S., Levenson, C. H., and Erlich, H. A. 1989. Genetic analysis of amplified DNA with immobilized sequence-specific oligonucleotide probes. Proc. Natl. Acad. Sci. USA 86:6230-6234.

37. Saunders, G. A., and Hancock, J. G. 1994. Self-sterile isolates of Pythium mate with self fertile isolates of Pythium ultimum. Mycologia 86: 660-666.

38. Schoen, C. D., Knorr, D., and Leone, G. 1996. Detection of potato leafroll virus in dormant potato tubers by immunocapture and a fluorogenic 5' nuclease RT-PCR assay. Phytopathology 86:993-999.

39. Stache-Crain, B., Mueller, D. G., and Goff, L. J. 1997. Molecular systematics of Ectocarpus and Kuckuckia (Ectocarpales, Phaeophyceae) inferred from phylogenetic analysis of nuclear- and plastid-encoded DNA sequences. J. Phycol. 33:152-168.

40. Van der Plaats-Niterink, A. J. 1981. Monograph of the genus Pythium. Stud. Mycol. 21:1-242.

41. Voordouw, G., Shen, Y., Harrington, C. S., Telang, A. J., Jack, T. R., and Westlake, D. W. S. 1993. Quantitative reverse sample genome probing of microbial communities and its application to oil field production waters. Appl. Environ. Microbiol. 59:4101-4113.

42. Wall, J., Cai, S., and Chehab, F. F. 1995. A 31-mutation assay for cystic fibrosis testing in the clinical molecular diagnostics laboratory. Hum. Mutat. 5:333-338

43. White, T. J., Bruns, T., Lee, S., and Taylor, J. 1990. Amplification and direct sequencing of fungal ribosomal RNA genes for phylogenetics. Pages 315-322 in: PCR Protocols, A Guide to Methods and Applications. M. A. Innis, D. H. Gelfand, J. J. Sninsky, and T. J. White, eds. Academic Press, San Diego, CA.

44. Yuen, G. Y., Craig, M. L., and Avila, F. 1993. Detection of Pythium ultimum with a species-specific monoclonal antibody. Plant Dis. 77:692-698. 